\title{
Die konteks vir die keuse van geriefsvoedsel van bepaalde beroepsvroue
}

\author{
Martha Kok en Priscilla Botha
}

\begin{abstract}
The purpose of this research is to understand and describe the context in which career women choose, purchase and use convenience food (CF). A person is rarely isolated from or unaffected by factors in his/her context/environment. The context also helps to give meaning to the behaviour of people. The choice of an ecological framework as an organising tool for this study is therefore selfevident. The two most relevant environments or contexts in which a household functions are the socalled proximal or close, and distal or societal environments of the ecological framework. The close environment includes the social and physical subsystems. For this research, the social subsystem refers to the people for whom the food is intended, the type of meal and whether the meal occurs during the week or weekend. This may influence the type of food chosen. The physical subsystem refers in this case to the type of dwelling, e.g. whether it is a single freestanding unit or a townhouse (in which space is mostly limited). The societal environment refers inter alia to the economic and sociocultural subsystems. Understanding the interaction patterns among and within the various subsystems of these environments can contribute to an understanding of the complexity of choosing, buying and using CF.
\end{abstract}

A qualitative research methodology and a grounded theory approach were used in the study. A theoretical sample was drawn to get to know more about the object of study. With this sampling technique, the researcher, on the one hand minimises differences, and on the other hand, maximises differences between participants. In the end, eight career women were chosen as participants, who met the criteria for inclusion in the study sample (minimising differences). The criteria were (a) a professional career and (b) a working week of at least 40 hours per week. Differences between the cases were maximised by including

- participants of two age categories, namely 'Generation X' and 'Baby Boomers';

- single and married homemakers;

- some participants without children and some with children of different ages.

Basic individual interviewing and a projective technique were used to gather qualitative data. Cash slips, field notes and observations in the supermarket were used as additional sources of data and for triangulation purposes. Data analysis included open, axial and selective coding.

Considering the closer environment, the most salient findings were the following:
Social aspects are important when choosing CF. The preferences and likes of their spouses, children and guests seem to be considered when choosing CF. CF seems to be an acceptable choice for some of the married career women especially during the week when they are pressed for time, whereas single career women seem to use CF as a standard practice. For guests, food is often prepared from scratch. Only when guests arrive unexpectedly, CF would be considered. During weekends, a relaxed pattern regarding meal preparation seems to be the norm. Those who rely on CF during the week continue to do so during the weekends. Those who sometimes opt for CF during the week, tend to spend a little more time preparing 'easy' foods, such as salads.

The most salient findings within the distal environment were the following:

The spendable income of the household is a product of the economy. The more price sensitive 'Baby Boomers' view CF as too expensive, whereas the Generation X sees it as value for money and time saved, which are both scarce resources for this generation. The single participants living in townhouses employ part-time domestic workers, whereas the married participants living in freestanding dwellings employ full-time domestic workers. Full-time domestic workers assist in or do all the food preparation as well as various household chores. The accessible retail environment seems also to play a significant role in the choice of convenience food. Factors such as a convenient location, a clean, well-organised and friendly atmosphere and a one-stop shopping experience, favour the buying of CF. Finally, an indirect socio-cultural influence was evident in the choice of CF, such as partially prepared meat products suitable for a 'braai', a typical South African tradition.

\section{- Mrs M Kok}

Previously from the

Department of Consumer Science

University of Pretoria

- Prof P Botha

Department of Consumer Science University of Pretoria

* The data used for this article was generated for a M script titled Bepaalde beroepsvroue se persepsies van geriefsvoedsels in die keuse, aankoop en gebruik daarvan by $\mathrm{M}$ Kok under supervision of Mrs AT Viljoen and Prof $P$ Botha. A new (maybe different) frame of reference, the ecological framework, was used to interpret this article. 


\section{DOELSTELLING EN TEORETIESE AGTERGROND}

Die doel van hierdie artikel is om begrip te vorm van beroepsvroue se gebruik van geriefsvoedsel teen die agtergrond van hulle konteks en hoedanig die konteks bepalend is vir die keuse daarvan. Die sleutelkonsepte in die doelstelling, naamlik die konteks, geriefsvoedsel en die konseptualisering daarvan, vorm die raamwerk waarvolgens die skrywe georden is. Die beroepsvrou is as die eenheidsanalise ter sake.

Die doelstelling impliseer dat die konteks die keuse van geriefsvoedsel kan bepaal. Vir die kwalitatiewe navorser is dit belangrik dat gedrag in verband met die gebruik van geriefsvoedsel in bepaalde kontekste begryp word. Die konteks gee betekenis aan die spesifieke gebeurtenis of aksie (Babbie \& Mouton, 2001:272), of soos Taylor en Bogdan $(1984: 6,10)$ dit stel, mense verskil in hul optredes omdat hulle hulself in verskillende situasies bevind. Die konsep 'konteks' sal vanuit ' $n$ ekologiese raamwerk (Deacon \& Firebaugh, 1988:29-35; Bubolz \& Sontag, 1993:432-3) benader word. Volgens die aangehaalde skrywers kan die konteks vir gedrag gekonseptualiseer word as synde die nabyheid van die verskillende omgewings waarin die huishouding hom bevind en waarin die bepaalde gedrag (die kies van geriefsvoedsel) plaasvind (Bubolz \& Sontag, 1993:433). Daar word onderskei tussen die nabye en wyere (distal) omgewings asook die onderlinge interaksie tussen die omgewings en subsisteme. Die nabye omgewing omsluit die plek en tyd waarbinne mense hulle lewens organiseer asook die interaksie tussen gesinslede, familie en vriende (Deacon \& Firebaugh, 1988:31).

Vir hierdie studie is die nabye omgewing in verband gebring met die spesifieke maaltyd, tyd en tipe woning. Die sosiale aspekte is ook met die geriefsvoedselkeuse in verband gebring. So byvoorbeeld mag dit 'n hoofmaaltyd vir die huishouding gedurende die week of naweek wees, óf ' $n$ hoofmaaltyd waarheen gaste genooi is. Volgens Assael (1992:539) word verbruikersgedrag beter verstaan as die spesifieke geleentheid of situasie in gedagte gehou word. Dit bepaal die tipe produkte wat verbruikers koop asook die prys wat verbruikers bereid is om te betaal. Tydsdruk gedurende die week kan byvoorbeeld ' $n$ belangrike oorweging wees vir die keuse van geriefsvoedsel, terwyl daar oor naweke meer vrye tyd beskikbaar is vir maaltydbereiding of ander aktiwiteite (Sloan, 1999; Tillotson, 2001). Net so mag gaste ook bepaalde voedselkeuses meebring (Verlegh \& Candel, 1999).

Die wyere omgewing omsluit die maatskaplike sisteme soos die ekonomie en die sosiokulturele subsisteme asook die mensgemaakte omgewing (Deacon \& Firebaugh, 1988: 32-35). Omstandighede wat met die hoofmaaltydsituasies verband hou, mag met die faktore uit die wyere omgewing in verband gebring word. Die ekonomiese subsisteem behels byvoorbeeld die koop of verkoop van goedere en dienste (Deacon \& Firebaugh, 1988:35). Die beroepsvrou se besluite rondom (geriefs)voedsel-uitgawes hou direk verband met haar besteebare inkomste, wat haar lewenstyl tot ' $n$ groot mate bepaal en wat moontlik ' $n$ vraag in die (geriefsvoedsel-) mark veroorsaak. Die mensgemaakte omgewing soos die stedelike omgewing met winkels waar die voedselkeuse plaasvind, mag ook ter sake wees. Verder kan kulturele voedselgebruike (in die studie is blanke, Afrikaanssprekende vroue die deelnemers) ook ' $n$ rol speel in die keuse van geriefsvoedsel, aangesien kultuur die riglyn verskaf waarvolgens mense optree (Deacon \& Firebaugh, 1988:33; Asp, 1999). Sims (1981) gebruik ook die ekologiese raamwerk om studies oor voedselkeuse, wat 'n komplekse, dinamiese proses is (Krondl \& Coleman, 1988; Shepherd \& Sparks, 1994:204; Asp, 1999; Blades, 2001), te orden.

Vanweë die veelvuldige rolle wat hulle vervul, mag vroue wat voltyds werk, relatief min tyd, energie en ook kognitiewe energie aan huishoudelike aktiwiteite bestee (Kok, 2003: 87-89, 127-130). Geriefsvoedsel bied ' $n$ minstens gedeeltelike 'n oplossing vir die voorsiening van maaltye aan hierdie groep verbruikers. Geriefsvoedsel word beskou as enige volledig of gedeeltelik voorbereide dis, voedselproduk of bestanddeel, waarby voorbereidingstyd en/of kulinêre vaardighede en/of energie-insette van die individu se kombuis na die voedselindustrie gekanaliseer is (Kok, 2003:19). Uit die definisie is dit duidelik dat die industrie ten doel het om onder meer tyd en 'energie' aan die verbruiker te verkoop ten einde haar aandeel in maaltydbereiding te verminder (Kok, 2003:158).

Om dié doel te bereik, word die resultate in twee dele aangespreek om begrip te vorm van hoe

- die nabye omgewing, en

- die wyere omgewing

kontekstueel bydra tot die keuse van geriefsvoedsel.

\section{NAVORSINGSONTWERP}

'n Ideografiese, kontekstuele navorsingstrategie en kwalitatiewe navorsingstegnieke is gevolg om bogenoemde doel te bereik (Babbie \& Mouton, 2001:270, 272).

\section{Deelnemers}

Beroepsvroue wat minstens 40 ure per week professionele diens lewer, is gekies omdat hulle gewoonlik tydsdruk ervaar en omdat die verantwoordelikheid van voedselaankope en -bereiding steeds grotendeels by vroue blyk te lê (Gofton, 1995; Candel, 2001; Davies, 2001). Vrywilligers is met behulp van doelbewuste steekproeftrekking (Strydom \& Venter, 2002:207; Babbie \& Mouton, 2001:166, 277) gewerf. Deelnemers is op grond van verskille soos ouderdom, huwelikstatus en gesin wat die keuse, aankoop en gebruik van geriefsvoedsel kan rig (Madill-Marshall et al, 1995; Brech, 1998; Sloan, 1998; Candel, 2001; Jae et al, 2000; Levy \& Weitz, 2001:113-116), ingesluit in die studie (Hammersley \& Atkinson, 1995:42). Agt deelnemers is daarvolgens gekies. Die deelnemers se demografiese en ander eienskappe word in Tabel 1 beskryf. Die deelnemers is met letters van die alfabet onderskei om verwysing in die bespreking van die resultate te vergemaklik. 
TABEL 1: $\quad$ DEMOGRAFIESE EN ANDER EIENSKAPPE VAN DIE DEELNEMERS $(\mathrm{n}=8)$

\begin{tabular}{|l|l|l|l|l|}
\hline $\begin{array}{l}\text { Beroep van die } \\
\text { deelnemer }\end{array}$ & Ouderdomsgroep & Huwelikstaat \& gesin & Woning & Huiswerker \\
\hline Personeelbestuurder & Generasie X* & Enkel & Meenthuis & Deeltyds \\
\hline Lektrise & Generasie X & Enkel & Meenthuis & Deeltyds \\
\hline Inligtingkundige & 'Baby boomer'^ & Enkel (weduwee) & Meenthuis & Deeltyds \\
\hline Lektrise & Generasie X & Getroud, sonder kinders & Meenthuis & Deeltyds \\
\hline Lektrise & Generasie X & Getroud met 2 kinders onder 6 jaar & Huis & Voltyds \\
\hline Personeel-bestuurder & Generasie X & Getroud met 3 kinders onder 7 jaar & Huis & Voltyds \\
\hline Lektrise & Generasie X & Getroud met 2 kinders onder 6 jaar & Huis & Voltyds \\
\hline Onderwyskundige & 'Baby boomer' & Getroud, met 2 volwasse kinders & Huis & Voltyds \\
\hline
\end{tabular}

* $\quad$ Generasie X verteenwoordig persone wat tussen 1965 en 1976 gebore is, terwyl 'Baby Boomers' tussen 1946 en 1964 gebore is

\section{Data-insameling}

Individuele onderhoude en ' $n$ projektiewe tegniek is gebruik vir data-insameling. Verskillende tegnieke van data-insameling vul mekaar aan en dien as kruisvalidasie wat die geloofwaardigheid van die data verhoog (Leedy \& Ormrod, 2001:105; Babbie \& Mouton, 2001:275, 278). Die data wat met die verskillende tegnieke ontgin is, is met mekaar vergelyk en in een datastel geïntegreer.

Individuele onderhoude wat 'n doelgerigte gesprek rondom ' $n$ spesifieke onderwerp tussen ' $n$ onderhoudvoerder en 'n deelnemer impliseer, is as een van twee data-insamelingstegnieke gebruik (Greeff, 2002:292; Neuman, 2000:273; Babbie \& Mouton, 2001:289; Botha, 2001). Twee individuele onderhoude is met ses deelnemers gevoer. Twee deelnemers was nie beskikbaar vir 'n tweede onderhoud nie. Die onderhoude is in die deelnemers se huise of kantore gevoer op geleë tye (Lautman, 1982; Lawless \& Heyman, 1998:528; Babbie \& Mouton, 2001:292). Die deelnemers is vooraf verseker dat hulle individuele menings oor geriefsvoedsel waardevol sou wees en dat daar geen regte of verkeerde antwoorde is nie. Die onderhoude is met toestemming op oudioband opgeneem (Babbie \& Mouton, 2001:277) sodat die oorspronklike data behoue kon bly. Die onderhoude het elk gemiddeld 'n uur geduur.

Temas (sien hieronder) is gebruik om die gesprek te fasiliteer sonder om dit te lei of te beperk (Babbie \& Mouton, 2001:273), maar ook om te verhoed dat die gesprek afdwaal en onnodige tyd verkwis word. Die navorser se interpretasie is met die deelnemers geverifieer (Babbie \& Mouton, 2001:277, 289). Gesprekvoering is volgehou totdat die navorser seker was dat inligting oor al die relevante aspekte ingewin is, ter wille van die geloofwaardigheid van die data (Calder in Lautman, 1982; Leedy \& Ormrod, 2001:106; Lawless \& Heyman, 1998:525; Babbie \& Mouton, 2001:277)

Die temas waaroor deelnemers gepols is, was die volgende:

- Wanneer word watter tipe geriefsvoedsel gebruik (pols vir week, naweek, gaste - redes).
- Hoe die gebruik van geriefsvoedsels verband hou met:

- gesinsvoorkeure - mans, kinders, ander

- ekonomiese faktore (moontlik ook huiswerkers)

- kultuur

- plek van aankope (of selfs die handelsmerk).

Kasregisterstrokies is as addisionele databron gebruik om die aankope van geriefsvoedsel te bevestig. Veldnotas is tydens en na die onderhoude gemaak, wat die navorser se indrukke van die gesprek, die deelnemer, en konseptuele en teoretiese notas ingesluit het (Oakley, 1981:31; Decrop, 1999; Babbie \& Mouton, 2001:275). Veldnotas dra by tot die bevestigbaarheid van die data (Guba en Lincoln in Babbie \& Mouton, 2001:278). Hierdie data is by die verbatim-transkripsies gevoeg.

Projektiewe tegnieke word soos volg gedefinieer: "Projective techniques provide verbal or visual stimuli which, through their indirection and concealed intent, encourage respondents to reveal their unconscious feelings and attitudes without being aware that they are doing it" (Will et al, 1996). Volgens dié skrywers verskaf verbruikers soms vals of misleidende antwoorde wanneer hulle op die man af oor produkte uitgevra word. Met projektiewe tegnieke word die kollig van die deelnemer weggeneem, wat deelnemers in staat stel om hul dieperliggende opinies te lug sonder die vrees van 'n persoonlike ontbloting (Hollander, 1988; Will et al 1996; Catteral \& Ibbotson, 2000). Die opinies van die deelnemers is dus op indirekte wyse meegedeel, en dit is vergelyk met die data wat tydens die onderhoud ingewin is (Kok, 2003:47). Projektiewe tegnieke motiveer deelnemers om ' $n$ binne-perspektief te gee in plaas van stereotipiese antwoorde (Solomon, 1994:25), wat die geloofwaardigheid en geldigheid van die data verhoog (Lawless \& Heyman, 1998:534; Decrop, 1999).

Vir die doel van hierdie studie is ' $n$ konstruksie-projektiewe tegniek ontwerp wat die deelnemers na die eerste onderhoud in hul eie tyd kon voltooi. Die deelnemers is versoek om ' $n$ konsep-televisie-advertensie vir geriefsvoedsel te formuleer waarin die teikengroep, beskrywing van die produk en die storielyn of idee uit- 
eengesit moes word. Die teikengroep wat die deelnemer gekies het, is vergelyk met haar eie demografiese profiel, soos haar huwelikstaat, ouderdom en kinders. Die produkte wat gekies is en die eienskappe wat genoem is, is vergelyk met die tipe produkte wat sy koop. Die storielyn is gebruik om iets van haar identiteit te wete te kom en dit in verband te bring met wat sy tydens die onderhoud genoem het. Hiermee kon die deelnemer se algemene positiewe of negatiewe persepsie van geriefsvoedsel, gekontroleer word.

\section{Data-analise}

Data-analise is volgens die stappe van ' $\mathrm{n}$ 'grounded theory'-benadering gedoen (Neuman, 2000:145-146; Babbie \& Mouton, 2001:498-501; De Vos, 2002:345351). Strauss en Corbin (in Babbie en Mouton, 2001:498) definieer 'grounded theory' soos volg: "A grounded theory is one that is inductively derived from the study of the phenomenon it represents. That is, it is discovered, developed and provisionally verified through systematic data collection and analysis of data pertaining to that phenomenon. Therefore, data collection, analysis and theory stand in a reciprocal relationship with each other. One does not begin with a theory, then prove it. Rather, one begins with an area of study and what is relevant to that area is allowed to emerge." Die kern van die benadering is dus dat eerste-orde konsepte uit Wêreld 1 (die leefwêreld van die oningewyde) (Babbie \& Mouton, 2001:7) gebruik word om letterlik 'n teorie van die grond af op te bou. Oop, spil- en selektiewe kodering is gebruik. Oop kodering behels die kategorisering van dele van die datastel. Vir elke hoofkategorie word dimensies en indikatore geïdentifiseer. Met spilkodering word die kategorieë binne konteks geplaas, terwyl met selektiewe kodering ' $\mathrm{n}$ kategorie stelselmatig met ander kategorieë in verband gebring word, en die verwantskap gevalideer word en moontlik verder verfyn word om sodoende by ' $n$ nuwe samehang of die verfyning van ' $n$ teorie uit te kom.

\section{RESULTATE EN BESPREKING}

\section{Die bydrae van die nabye omgewing tot die keuse van geriefsvoedsel}

Die nabye omgewing bestaan uit die fisiese en sosiale subsisteme (Deacon \& Firebaugh, 1988:30). Oop kodering is eerstens gebruik om die relevante konsepte te identifiseer en daarna is temas met behulp van spilen selektiewe kodering ontwikkel. Enkele verbatim aanhalings word gegee om die resultate te staaf. Die sosiale aspekte wat voedselkeuse kan beïnvloed, word eerstens bespreek en daarna word dit binne ' $n$ raamwerk van tyd en fisiese omgewing geplaas.

Sosiale aspekte Sosiale aspekte dui op die interaksie wat diel lede van die gesin of huishouding met mekaar en ander mense soos familie en vriende het (Deacon \& Firebaugh, 1988:31). Rondom elke voedselgebeurtenis word ' $\mathrm{n}$ ryk tapisserie van sosiale en kulturele betekenis geweef. Vriendskappe, gesinsbande, kameraadskap, besorgdheid oor ander en vele meer word uitgedruk in sosiale interaksie wat gewoon- lik rondom voedsel plaasvind (Fieldhouse, 1995:7879). Furst et al (1996) wys ook daarop dat die persoon wat voedselkeuses vir die huishouding maak, die smake, voorkeure en behoeftes van ander in die huishouding in ag neem om harmonie in die huishouding te verseker. Gesinsmaaltye (met geriefsvoedsel berei) kan dus genotvolle geleenthede wees waar die fisiese sowel as sosiale behoeftes van gesinslede bevredig word. Positiewe terugvoer oor maaltye versterk die selfpersepsie van die een wat daarvoor verantwoordelik was; geriefsvoedsel wat kan 'help' om aan die verwagtings van byvoorbeeld 'n goeie vrou, ma of gasvrou te voldoen, sal gevolglik in die geheue-skemata gestoor word met positiewe assosiasies van die betrokke konteks. Olson (1981:76) wys daarop dat die skemata of kennis, baie konteks-spesifiek is en dit blyk ook duidelik in hierdie studie.

Die man in die gesin Mans se voorkeure word deurgaans in ag geneem. Deelnemer (e) vertel hoe sy geriefsgeregte geur en spesiaal voorberei dat haar man nie eens agterkom sy het ' $n$ 'kortpad' gekies nie. Sy voel goed daaroor en almal in haar huishouding is gelukkig en tevrede met die maaltye wat sy voorsit. “... my man is nogal een van daai wat half nog hou van dit wat jy nog jou eie persoonlike ietsie insit. Hy sê baie keer daai kos proe plastiekerig - dit proe nie soos die goed wat jy self maak nie ... Wat vir my lekker is, is as ek so een kan maak sonder dat my man agterkom dis geriefskos gewees. So ek sit nog steeds my eie persoonlike ... hy gee nie om nie en dis vir hom die wonderlikste kos - so dis vir my great."

Soms, waar die man en vrou se voorkeure verskil ( $f$ en g), word toegewings gemaak om die harmonie in die huis te bewaar.

"Man, hy sal baie eerder ... take-aways is vir hom glad nie lekker nie ... hy sal eerder ' $n$ vleisie braai. As ek sê kom ons eet sommer hamburger en chips, sal hy sê, vir dieselfde prys eerder vleis braai. So ek dink dit maak dat ons nog minder geriefsvoedsels gebruik. Wegneemetes bitter min."

Deelnemer (f) het aangedui dat haar man dink dat geriefsvoedsel duur is, en verder dat sy grootgeword het in ' $n$ huis waar voedsel van meet af met onverwerkte bestanddele berei is. Sy het egter haar huidige omstandighede in ag geneem en besluit dat geriefsvoedsel vir haar die moeite werd is. Sy koop daarom deesdae gedeeltelik voorbereide produkte, veral groente en visporsies. Hierdie aspekte hou ook verband met die enkulturasie van voedselgebruike.

“... hy het aanvanklik vir my gesê: sy ma-hulle het hulle grootgemaak dat jy alles vars koop en self maak, want dis die goedkoopste, en dit [geriefsvoedsel] was vir hom duur, tot ek op 'n stadium besluit het ek gaan nie meer verwerk nie. So ek gebruik omtrent nou ... net vir kook gebruik ek hierdie gevriesde goeters. My ma het byvoorbeeld ook nie vreeslik gevriesde goed gebruik nie, so dit kom uit die agtergrond uit en ek dink mens word net wyser op 'n stadium en besef, dis nie regtig baie slegter om dit te gebruik nie."

Die kinders in die gesin Kinders speel ' $n$ belangrike rol in die deelnemers ( $d$, e, $f$ en $g$ ) se besluitneming oor voedsel. Hulle voorkeure en behoeftes word 
in ag geneem en soms word hulle spesiaal bederf.

“... ek neem hulle in ag as ek weet hulle hou meer van sekere goed."

"Die pizza geniet hulle [die kinders] baie".

Kinders se voedingsbehoeftes beïnvloed hul moeders se voedselkeuses. Dit blyk dat hulle voorkeur gee aan verrykte produkte wat die nodige voedingstowwe aan hulle kinders sou kon voorsien. Produkte wat as sodanig bemark word, trek die aandag van werkende ma's omdat hulle dan gerus voel dat hulle kinders die nodige voedingstowwe sal inkry.

"Ek weet nie hoe waar dit is nie, ek weet nie hoeveel vitamienes kan daar in R... [rysvlokkies] wees nie, maar dit slaan vas. Mens glo dit [die bemarkingsboodskap] later."

Geriefsvoedsel dien ook as medium om sowel kinderopvoeding as die sosialisering van kinders in bepaalde rolle te fasiliteer. Wanneer ' $n$ ma en haar kind saam koek bak of saam voedsel voorberei, bevredig dit van haar dieperliggende behoeftes om kwaliteit-tyd en -aandag aan haar kind te bestee, en sy sosialiseer ook die kind in die aanleer van vaardighede en in die gebruik van bepaalde produkte. Dit kan haar selfpersepsie as ma positief beïnvloed. Die kind stoor dan sowel produkkennis as die positiewe ervaring in die geheue; later dien dit as verwysingsraamwerk wanneer hy / sy self eendag voedselaankope moet doen. Jong kinders (Generasie $Y$ en jonger) wat nog nie die wêreld van verbruikersbesteding betree het nie, sal waarskynlik dié generasie wees vir wie geriefsvoedsel die norm sal wees (Sloan, 1998).

Enkellopendes Gesinsmaaltye is gewoonlik ' $n$ sosiale geleentheid met positiewe konnotasies vir baie mense. Die enkelpersone ( $a, b$, en $c)$ dui aan dat dit nie lekker is om vir hulleself kos te maak of om alleen te eet nie, daarom probeer hulle om dit so gou en moeiteloos moontlik af te handel:

“... [saans] is ek regtig nie lus vir kosmaak nie ... veral as dit vir myself is."

"... dan gryp ek die maklikste ding wat ek kan kry ..."

Die behoefte om voedsel saam met ander te geniet, is ' $n$ dieperliggende behoefte wat enkellopendes ervaar. Enkellopendes was tydens hul kinderjare deel van ' $\mathrm{n}$ gesin, van watter aard ook al, wat voedselervarings met mekaar gedeel het, en wanneer hulle die ouerhuis verlaat, is hulle op hulself aangewese vir maaltye. Hulle probeer so gou as moontlik iets eet wat nie te veel moeite is om te berei nie. In teenstelling hiermee, is die geïnternaliseerde verwagtings dat ' $n$ 'ma' of 'vrou' verantwoordelik is vir maaltydbereiding, motivering om dit wel te doen. Geriefsvoedsel is dus van belang vir enkellopendes wat hulleself moontlik sou kon afskeep met die voorbereiding van gesonde maaltye, net omdat hulle alleen is.

Die volgende aanhalings van ' $n$ jong, ongetroude deelnemer (a) en van ' $n$ weduwee $(h)$ weerspieël dit goed:

“... om vinnig iets te eet, om die honger weg te kry. ... As ek ' $n$ gesin kry ... dan sal ek meer fokus op kosmaak ..."
"Maar toe ek getroud was en die kinders klein was, was dit ook weer anders. Jy kook dan meer vir die kinders ... As dit vir ander mense is, sal ek meer moeite doen. Vir myself wil ek regtig nie tyd spandeer nie."

Geriefsvoedselkeuse binne 'n raamwerk van tyd en tuiste Die Geriefsvoedselkeuse binne ' $n$ raamwerk van tyd en tuiste word bespreek na aanleiding van die verskillende patrone van maaltye wat gedurende die week en oor naweke gehandhaaf word.

'n Patroon gedurende die week van dié gesinne wat in huise woon Vir gesinsmaaltye (deelnemers e, f, g en h) gedurende die week blyk 'n gekookte maaltyd wat hoofsaaklik van onverwerkte bestanddele berei word, die norm te wees. So 'n 'gekookte' maaltyd bestaan gewoonlik uit vleis-, stysel- en groentegeregte wat op verskillende maniere voorberei kan word. Soms word ook ligte geregte, soos makaroni en kaas, met slaai bedien. Dié spesifieke deelnemers het die hulp van voltydse huiswerkers wat die grootste gedeelte van die voorbereiding hanteer, sodat afrondingswerk aan die maaltyd of die voorbereiding van ' $n$ slaai al is wat vir die deelnemer oorbly om te doen. Dit spaar heelwat tyd vir die deelnemer.

"In die week eet ons meer regte gekookte kos soos boontjies en pampoen en rys en hoender en sulke tipe van goed. Sy [die huiswerker] kook ook twee of drie aande van die week alles - sy maak hoender en groente - sy maak die hele ete. Ander aande sal sy byvoorbeeld net macaroni en kaas maak en dan maak ek ' $n$ slaai by. Of sy sal aartappels kook en ek sal vis in die oond sit met slaai by of met gevriesde groente by."

“... ek het 'n dierbare huiswerker wat elke dag kosmaak. So wat ek baie keer doen, ek sit net 'n bietjie geur by. Dis maar die gewone rys, vleis, aartappels, pampoen en boontjies. As sy hoender berei het, sal ek 'n sousie maak."

Die feit dat ' $n$ huiswerker die voorafbereiding van die maaltyd behartig, verklaar moontlik waarom hierdie deelnemers geredelik vars produkte aankoop vir hoofmaaltye gedurende die week, maar ook geriefsprodukte, soos bevrore visporsies en groente, vir tye wanneer sy self die voorbereiding moet doen of wanneer sy onbepland later as normaalweg moet werk. "... die feit dat jy 'n huiswerker het wat die tyd het om dit te doen, speel verseker ' $n$ rol in die tipe van goed wat jy koop. ... as ek dink byvoorbeeld aan pampoen skil - dis nogal iets wat "n hele rukkie vat."

"... as ek besef ek gaan laat eers by die huis kom en ek moet vinnig ietsie maak wat ten minste bietjie voedsaam is vir die kinders - dan sal ek die stirfry groente [bevrore groente] maak en 'n ou vleisie daarby braai of die petit pois met mash. Ek koop nou nogal deesdae die S... pakkies [kits kapokaartappel]."

Een deelnemer (e) koop egter geriefsvoedsel, selfs al het sy ' $n$ voltydse huiswerker omdat sy van mening is dat haar huiswerker ' $n$ veeleisende taak het om die hele huishouding en die versorging van haar twee klein kindertjies te behartig. Daarom maak sy dit vir haar huiswerker ook makliker. 
“... omdat sy ook die volle huishouding bestuur, sy doen die kinders en wasgoed en alles en dis nie asof ek twee [huiswerkers] het nie - een maak die kos en een nie - sy het " $n$ redelike vol dag - so ek gaan vir haar ook die goed koop wat maklik is om te maak."

‘n Patroon gedurende die week van dié enkellopendes wat in meenthuise woon 'n Gekookte maaltyd is ook by enkellopendes ( $a, b$ en c) die gebruik. Die jonger deelnemers ( $a$ en $b$ ) gebruik meestal geriefsprodukte wat in die oond gebak of in die mikrogolfoond gaargemaak kan word. Hulle doen dit moontlik omdat hulle baie ekstra tyd aan hul beroepe bestee en ook nie die hulp van voltydse huiswerkers het om hulle met allerlei huistake by te staan nie.

"... omdat my werk soveel tyd vat, veeleisend is, het ek nie baie tyd in die aand nie. Ek is moeg en nie lus om kos te maak nie en dan gryp ek die maklikste ding wat ek kan kry soos 'n blikkie tuna oopmaak ... en ... baie geriefsvoedsel soos daai chicken kiefs wat mens net vinnig in die oond druk en terwyl dit bak kan mens nog gou ander werk klaar maak en doen."

Hulle is moontlik ook meer geriefsgeoriënteerd omdat hulle nie hulp van voltydse huiswerkers het nie. Hulle huiswerkers werk op ' $n$ deeltydse basis, soos een keer per week, en dan maak sy hoofsaaklik die meenthuis aan die kant. Dit bring mee dat hulle self vir die meeste ander take, soos maaltydbereiding en die gepaardgaande opruim, verantwoordelik is.

"Ek het ' $n$ huiswerker wat een maal ' $n$ week inkom op 'n Saterdagoggend en sy was skottelgoed - dis omtrent wat sy doen en sy maak skoon. ... So met die gevolg, deur die week wil jy nie baie skottelgoed hê nie."

Die ouer enkellopende deelnemer (c) koop hoofsaaklik onverwerkte voedsel wat sy volgens haar 'ou' resepte voorberei. Sy vries ook daarvan vir latere geleenthede en berei dus so haar eie geriefsvoedsel. “... gisteraand het ek bobotie gemaak. Toe maak ek drie bakkies. Ek maak nie klein maat nie, dit is absoluut tydmors. Drie bakkies en ek sit dit in die vrieskas" en "... dit pla my glad nie om opgewarmde kos te eet nie... van die vorige aand presies dieselfde kos te eet nie."

Sy sorg egter dat sy geriefsprodukte aankoop en in haar vrieskas bêre vir die kere wat sy laat werk, nie lus het om kos te maak nie, by haar bejaarde ma in die ouetehuis kuier of tyd aan haar stokperdjies spandeer.

"Nee kyk, ek eet dit min - ek sal nie meer as een keer 'n week so tipe ding (vis in sous) eet nie en ek sorg darem dat ek dit in die vrieskas het vir ingeval ek laat by die huis kom ... jy maak daai ding sommer in die mikrogolf gaar en jy sit ' $n$ slaaitjie daarby en dan het jy 'n hele ete."

Die jonggetroude deelnemer (d) vertel dat sy normaalweg op weeksaande kitsmaaltye (of te wel gereed om te eet maaltye) koop, aangesien sy voel dat haar werk en studies baie veeleisend is en sy ook nog haar 'nuwe' huwelik wil vestig. As sy egter op ' $n$ aand tyd het, maak sy van geriefsprodukte wat min moeite verg en vinnig gaar word, gebruik.

"... elke aand kom ek by die S... Ek gaan min of meer so $18: 30$ se kant en dan loer ek wat het hulle en wat lyk vir my lekker en ek hou in gedagte wat het ons die vorige aand en die vorige aand en dat dit nou bietjie tyd is vir vis in plaas van dit. Maar dit hang ook af van my tyd. As ek die aand 'n bietjie meer tyd het, sal ek byvoorbeeld vis vat wat jy net kan bak, want daar is 20 minute en Mc... se oven chips wat $50 \%$ minder vet het as ander en dan sal ons dit bak in die oond. Die ander aande wat mens minder tyd het, kyk mens maar wat is daar en dan dink ek maar... beplan ek in my agterkop wat het ons gisteraand en die aand voor dit geëet, en jy probeer dit in gedagte hou en 'n nuwe verskeidenheid vir die aand bring of koop."

Voedselkeuse gedurende die naweek Al die deelnemers het getuig dat hulle oor naweke ontspanne is en 'maklike kos' eet. Die verwysing na 'ons' dui op die sosiale interaksie tussen die gesinslede oor naweke en met 'maklike kos' word bedoel dat daar nie noodwendig gekookte kos berei word nie, maar eerder geregte soos braaivleis, slaaie, braaibroodjies, aartappelgeregte en dies meer. Dit lyk dus of geriefsvoedsel nie so prominent oor naweke is nie, want dan is daar tyd om voedsel voor te berei en daar word oorwegend geregte gemaak wat die minimum voorbereiding en gaarmaak benodig.

“... oor naweke is ons definitief meer ingestel om te braai en braaibroodjies te maak en sulke tipe van goed. Ons sal byvoorbeeld nooit oor ' $n$ naweek boontjies en pampoen kook nie. Dan sal ons meer slaai eet en sommer vrugteslaai maak by kos en vinniger tipe van kos maak."

Die vleis wat vir die braaivleis oor naweke aangekoop word, is dikwels vooraf gedeeltelik berei, soos gemarineerde vleis, en dit verskil van die vleis wat vir die week aangekoop word. Per geleentheid is deelnemers (c, e, $g$ en $h$ ) dus bereid om meer te betaal vir spesiale produkte. 'n Slaghuisbestuurder van ' $n$ bekende supermarkgroep bevestig dat die omset van sosaties, kebabs, gemarineerde vleis en hoenderprodukte oor naweke toeneem. Dit verteenwoordig egter die kliëntebasis van die supermark en nie noodwendig die keuses en gebruik van die deelnemers aan hierdie studie nie.

“... jy koop maar jou gewone maalvleis en steak en chops en jou gewone vleis wat jy dan koop ... ek koop eerder die regte sosaties by die slaghuis en braai dit in die aand of so iets."

Dit blyk dat selfs die deelnemers met voltydse huiswerkers (e, $f, g$ en $h$ ) oor naweke self die grootste deel van die maaltydbereiding behartig, tensy hulle spesiale reëlings met hul huiswerkers tref.

"Naweke, van Vrydae, Saterdae en Sondae maak ék kos en obviously as ons nou mense kry."

"... want dan het ek die tyd en dan beplan mens vooraf so, dan sal ek byvoorbeeld dat my huishulp my help die groente solank sny en dan sal ek dit net gaarmaak."

Soms word daar kitskos of volledig voorbereide geregte oor die naweek gekoop, aangesien naweke as 'be- 
derftyd' beskou word en die tyd eerder saam met gesinslede of vriende deurgebring word (deelnemers $a$, b, c, d, e, f, en h). Dit word ook soms gedoen omdat die persepsie bestaan dat kitskos oor naweke 'toelaatbaar' is omdat daar gedurende die week ' $n$ gesonde gebalanseerde maaltydpatroon gevolg is. Sulke maaltye verseker dat daar min voorbereiding en skottelgoed, indien enige, is. Hierdie tendens stem ooreen met Amerikaners wat gereeld kitskos of wegneemetes bestel in ' $n$ poging om hulle lewens te vereenvoudig en die voorspelling word gemaak dat die gewildheid van tuisaflewerings en internetaankope van kos sal toeneem namate tydsdruk groter raak (Sloan,1999).

“... naweke gaan ons soms S... [gesinsrestaurant] toe, spesifiek, want die kinders kan daar speel - as ons gaan uiteet. Andersins koop ons take-aways pizzas veral."

"Naweke baie meer vetterigheid, baie meer takeaways, baie ongesond eintlik. En definitief dan maak ons gebruik van Mr D... Saterdagaande, of ons eet uit of ons skakel Mr D... en hulle laai by jou huis af en dis goed soos baie olierige pizzas en St... of wat ook al nou daar is in die Mr D... menu. Ultra gerief en ek wil ook nie eens uit ' $n$ bord uit eet nie - ons gooi die houertjies in die asblik."

"... naweke is ek nog meer lui as in die week. Oor naweke voel dit vir my gaan dit waarvoor ek lus is vir die oomblik en vir die minste moeite. In die week probeer ek gebalanseerd groente te maak en so aan, maar naweke, veral Sondae - dis vir my heerlik om van daai klaar geregte te koop."

Enkele deelnemers ( $\mathrm{a}$, e en $\mathrm{h}$ ) geniet dit egter om oor naweke ' $n$ bietjie meer tyd in die kombuis te spandeer omdat tyd dan beskikbaar is. Hoewel daar dan hoofsaaklik van vars, onverwerkte bestanddele gebruik gemaak word, word daar tog ook van geriefsvoedsels gebruik gemaak, soos bakmengsels of klaargemaakte souse. Sloan (1999) wys daarop dat die tendens om voedselbereiding oor naweke vir ontspanning te doen, besig is om af te neem.

"As ek op 'n naweek tyd het dan bak ek al die muffins ['n geriefsbakmengsel] en ek vries [dit] ... dan kan ek dit vir ontbyt net vinnig in die mikrogolf druk en dis ' $n$ vullende ontbyt en ek is op my pad ..."

"Ja, naweke het mens meer tyd. ... Sondag [sal ek] gou gaan en gaan groente koop by die groentewinkel en dit dan voorberei.

Geriefsvoedsel, soos vakuumverpakte beetslaai, kerriewortelslaai of aartappelslaai in netjiese kartondosies, bied die voordeel dat dit maklik ingepak en gebruik kan word op ' $n$ ander bestemming weg van die huis. Dan is daar geen voorbereiding betrokke nie. Sulke produkte word spesiaal deur deelnemer (g) gekoop vir geleenthede soos 'n naweek weg.

"Ander geriefsvoedsels wat ek gebruik is daai pakkies boontjies - soos daai kerrieboontjies [wat] in die sakkies is. Dit gebruik ek nogal baie. En dit gebruik ek veral as ons weggaan. Dan is dit vir my ' $n$ vreeslike maklike ding om saam te vat. So dit koop ek definitief."

'n Patroon van deelnemers oor naweke wanneer hulle gaste onthaal Al die deelnemers verkies om voedsel self voor te berei vir gaste. Verlegh en Candel (1999) het ook bevind dat wanneer gaste vir ete genooi word, voorbereide geriefsgeregte waaraan eienskappe soos 'maklik om voor te berei' en 'goedkoop' gekoppel word, nie positiewe persepsies ontlok nie.

"Wel, uit die aard van die saak is my gaste altyd vir my belangrik. Ek sou sê ... dit gee net daai ekstra tikkie van ek gee om."

"... maar dan kry ek tog oor naweke klomp mense en dan maak ek eerder my eie - as dit klomp is, maak ek eerder my eie slaaie, pap en sous, braaivleis en sulke tipe van goed ..."

Dit blyk dat gaste hoofsaaklik oor naweke genooi word aangesien daar dan meer vrye tyd beskikbaar is. Daar word normaalweg vleis gebraai vir gaste, ' $n$ tipies Suid-Afrikaanse manier van onthaal wat baie ontspanne en gemaklik is. Almal, mans en vroue, kuier saam om die vuur in plaas daarvan om baie tyd in die kombuis deur te bring.

"En ek moet sê, die meeste van ons vriende het sulke klein kindertjies. So, vir hulle is dit ook makliker om net te braai en buite te speel, die kinders, as wat ons almal gaan aansit en voorgereg, hoofgereg en nagereg."

Dit blyk dat vleis spesiaal gekoop word vir gaste, soos fillet of sosaties.

"... fillet braai met gebraaide groente daarby of sulke goeters."

"Vir braaivleis koop ek soos sosaties, wat ek ook nie vir myself sal koop nie."

Heelwat deelnemers ( $a, b, c$, e en g) gebruik wel selektief geriefsprodukte wanneer hulle gaste onthaal, veral omdat dit tyd spaar.

"... dit is vir my lekker om mense te onthaal en veral as mens so uit die pakkie uit kan kosmaak kan jy baie mense nog flous daardeur, maar nietemin help dit jou baie met tydsbeplanning."

"Ek sou dalk nog ' $n$ pakkie muffins gaan koop in plaas van om dit van die begin af te maak. Dit sal ek doen as ek byvoorbeeld mense vir die naweek het en mens wil [dit voorsit] vir Saterdagoggend-ontbyt. Ek sal definitief nie as ek gaste het ' $n$ uur vroeër opstaan en vars muffins bak nie, so dit spaar tyd ook."

Een deelnemer (d) gaan voort met haar normale praktyk om volledig voorbereide maaltye en geriefsprodukte te koop vir gaste. Sy doen dan moeite met die dek van die tafel en die voorsit van die geregte. Sy vertel dat haar gaste altyd baie gevlei voel oor die spesiale moeite wat sy doen en dat dit haar in staat stel om te ontspan en die aand te geniet omdat sy weet dat alles professioneel lyk en heerlik smaak.

"Gaste ... sal ek gewoonlik bestel 'n groot bobotie en dan my bestelling plaas, gewoonlik saam met ' $n$ spesiale broodjie wat hulle dan bak en dan gaan haal jy dit net. En die rys en alles, kry jy dit klaar. ... En dan met ' $n$ braaivleis is dit natuurlik maklik - jy bestel ' $n$ klaargemaakte broodjie met kaas en tamatie storie, wat amper soos ' $n$ pizza is en jy kry by 'n spesifieke verskaffer worsrolletjies met ' $n$ sousie en samoosa- 
tjies wat jy as voorgereg kan bedien. En dan braai ons gewoonlik, en die slaai sal ek dan daai pakkie koop en 'n paar tamaties en 'n paar stukkies Griekse kaas ekstra sal ek ingooi. ... ek sal 'n tafel uiters mooi dek en natuurlik sal ek bakke vir gaste, maar vir my en my man maak dit nie saak nie. Vir gaste hou ek van mooi bakke, mooi opskeplepels, [en om die] tafel mooi te maak ..."

Geriefsvoedselprodukte word spesiaal aangekoop om voorsiening te maak vir onverwagse gaste al is dit nie normale praktyk wanneer gaste genooi word nie. Dit blyk dan belangriker te wees om gasvryheid te betoon en te kuier (deelnemers a en g) as om voedsel voor te berei en lank in die kombuis deur te bring.

“... wortelslaai en beetslaai wat jy in ' $n$ boksie koop en dit kan jy in jou kas hou vir baie lank vir ingeval daar mense kom."

"... as gaste onverwags opdaag is geriefsvoedsel tog die maklikste uitweg, maar as ek iemand spesiaal oornooi sal ek ' $n$ ete beplan en ... vooraf 'n slaai maak wat in die yskas gebêre kan word ..."

Dit wil dus lyk asof die deelnemers verskillende eetpatrone gedurende die week en naweek het en dat daar vir gaste ' $n$ ander stel reëls bestaan. Onthaalpatrone verskil dus van die alledaagse eetpatrone (Furst et al, 1996). Die geleentheid en omstandighede speel dus ' $n$ rol in die tipe voedsel wat gekoop en voorgesit word (Furst et al, 1996; Verlegh \& Candel, 1999; Kupiec \& Revell, 2001). Kennis hieroor in die geheue-skemata is baie spesifiek, soos gestel deur Olson (1981:76). Vir ander kultuurgroepe mag hierdie gebruike heeltemal verskil.

\section{Die bydrae van die wyere maatskaplike omgewing in die keuse van geriefsvoedsel}

Die maatskaplike omgewing is ' $n$ betekenisvolle deel van die gesin se ekosisteem. Daar is voortdurende interaksie tussen die onderskeie sisteme soos die sosiokulturele, politiese, ekonomiese en tegnologiese omgewings namate inligting, goedere en dienste uitgeruil word om die gesin of individu se behoeftes te bevredig (Deacon \& Firebaugh, 1988:32-33). Die sosiale omgewing verskaf dus die konteks waarbinne die deelnemers (oftewel verbruikers) funksioneer. Die getranskribeerde onderhoude is op induktiewe wyse (Babbie \& Mouton, 2001:273) bestudeer vir aspekte uit die wyere omgewing wat die aankope en gebruik van geriefsvoedsel mag beïnvloed.

Interaksie tussen die ekonomiese en fisiese omgewings Die ekonomiese sisteem is gebaseer op die aanbod van goedere en dienste deur die industrie en verbruikerskeuses wat die vraag in die mark beïnvloed (Deacon \& Firebaugh, 1988:35). Die keuses wat huishoudings as verbruikers (onder andere van voedsel) asook as produsente maak, beïnvloed die algemene ekonomie en die huishouding se hulpbronne. Beroepsvroue wat ' $n$ eie inkomste verdien of gesamentlik bydra tot die besteebare inkomste van die huishouding, beskik waarskynlik oor geld om geriefsvoedsel, wat duurder is weens die insette van die industrie, te koop. Voedselkeuses is ook gekoppel aan die plek / winkel waar dit gekoop word.

Interaksie van die huishouding met die ekonomiese omgewing Die ekonomiese omgewing impliseer die huishouding se inkomste en hulpbronne.

Pryssensitiwiteit Sommige deelnemers ( $a, d$ en e) koop geredelik geriefsvoedsel aan en is glad nie pryssensitief nie, aangesien hulle voel dat geriefsvoedsel die moeite werd is en dat hulle dit kan bekostig.

“... dis seker omdat ek self werk en my eie salaris verdien - kan mens dit half bekostig en ek betaal eerder daai paar rand ekstra as wat ek langer moet staan en werk ..."

“... ek het nie 'n idee wat kos dit as ek self sou voorberei nie ... Gisteraand - ek het nou die strokie gehou vir jou - is dit enige iets tussen R80 en R100 per aand, wat eintlik baie duur is, maar ek sien dit nou eers. Ek meen dit is nogal baie geld. So ja, ek is nie pryssensitief nie - vir my gaan dit oor die tyd wat ' $n$ mens spaar."

Meer pryssensitiewe deelnemers (soos $g$ en $h$ ) koop minder geredelik geriefsvoedsel omdat hulle van mening is dat geriefsvoedsel te duur is en dat hulle besteebare inkomste beperk is.

"... ons het nie baie geld nie ... mens koop maar binne jou finansiële raamwerk."

Vanuit ' $n$ verbruikersperspektief, beweer Assael (1992:269), bestaan daar ' $n$ direkte verband tussen inkomste en koopkrag. Navorsingsresultate oor die invloed van inkomste op die keuse van geriefsvoedsel is egter teenstrydig. Terwyl Rose et al (1995) geen direkte verband kon vind nie, het ander (Blaylock et al, 1999; Jae et al, 2000) weer bevind dat 'n hoër inkomste die kans vergroot dat geriefsvoedsel gekoop sal word. Beskikbare hulpbronne beïnvloed dus voedselkeuse (Furst et al, 1996). Dit was duidelik dat deelnemers se subjektiewe persepsie oor hul eie finansiële posisie hul gedrag ten opsigte van geriefsvoedsel beïnvloed.

Huiswerkers Om ' $\mathrm{n}$ huiswerker in diens te neem, het finansiële implikasies, soos die salaris wat betaal moet word. Al die deelnemers kon tot ' $n$ meerdere of mindere mate die dienste van huiswerkers bekostig om taakverligting in die huis te bied. Volgens Bonke (1996:296) is dit hoofsaaklik welvarende huishoudings wat huiswerkers kan bekostig.

Dit lyk of die deelnemers met gesinne, veral dié met klein kindertjies (e, f en g), voltydse huiswerkers het en minder geriefsvoedsel koop as die enkellopende deelnemers, wat deeltydse huiswerkers het. In huishoudings met voltydse huiswerkers word daar dus meer voedselbereiding gedoen (Bonke, 1996:316). Die take waarmee die huiswerkers help, wissel van opruim, skoonmaak, versorging van klere en maaltydbereiding tot die versorging van kinders. Huiswerkers is dus baie werd (in terme van tyd en energie) vir die deelnemers en veral vir diegene met klein kindertjies. Daar kan egter gevra word of die koste verbonde aan 'n voltydse huiswerker nie die besteebare inkomste van die huishouding sodanig kan raak dat minder ge- 
riefsvoedsel bekostig kan word nie. Eshleman (1994:130) wys verder daarop dat kindersorg, as dit elders gedoen word, baie duur is. 'n Huiswerker kan as 'n hulpbron beskou word om die werkslading van die beroepsvrou tuis te verlig, sodat sy haar tyd (wat ook ' $n$ rol in haar eie inkomste speel) volgens haar eie prioriteite kan bestuur. Tyd is ' $n$ multidimensionele entiteit wat deur verskillende mense verskillend bestuur en bestee word (Davies,1997).

Huiseienaarskap en toerusting Die persone wat aan hierdie studie deelgeneem het, besit almal hul eie huise of meenthuise. Meenthuise is kleiner en meenthuiseienaars ( $a, b, c$ en d) meld dat hulle net ' $n$ kombinasie ys-/vrieskas in die meenthuiskombuis kan inpas en hulle oor die algemeen ook minder pakruimte het vir ander kruideniersware. Die implikasie hiervan is dat daar minder vriesspasie is, sodat grootmaataankope van produkte wat gevries moet word, nie gedoen kan word nie.

"Ons bly in ' $\mathrm{n}$ meenthuis en spasie is redelik beperk ... daai vrieshokkie bo die yskas wat ons gebruik [is klein] ... ons koop soos wat ons eet ..."

"Ek koop 'n sout-en-pepermengsel, roosmarynsout ... en ek het 'n pynappel-en-gerooktesout-kombinasie. ... dit spaar ook pakplek, want my kombuis is klein."

Dit kan as een moontlike verklaring dien waarom meenthuiseienaars meer geriefsvoedsel aankoop en gebruik as huiseienaars, omdat hulle meer dikwels kleiner hoeveelhede voedsel aankoop. Huiseienaars kan groter hoeveelhede voedsel op ' $n$ keer aankoop, aangesien hulle meer bergruimte en ook groter vrieskaste het.

"Ek koop so een maal ' $n$ maand my redelike groot aankope en dan een maal ' $n$ week brood en melk. Dan koop ek sommer genoeg brode vir die hele week [en vries dit]. Dit spaar tyd en as jy so daaroor dink kan jy geld ook spaar, want as jy elke dag gaan, dan is daar elke dag iets wat vir jou lekker lyk, wat jy bykoop [en] wat jy dalk nie eers nodig het nie."

Manrique en Jensen $(1997 ; 1988)$ beweer dat huiseienaars minder geriefsvleisprodukte as huishuurders aankoop. Die argument berus daarop dat huiseienaarskap baie uitgawes meebring wat die besteebare inkomste kleiner laat. Hulle beweer verder dat huiseienaarskap ' $n$ groter gewilligheid om tyd aan voedselbereiding te spandeer, meebring. Aangesien al die deelnemers hulle wooneiendomme besit, kan dieselfde verklaring nie presies so toegepas word nie, maar gee dit tog ' $n$ mate van begrip.

Die deelnemers wat in huise woon, is getroude vroue wat deel is van dubbelberoep-gesinne. Oor die algemeen lyk dit of hulle minder geriefsvoedsel as die enkellopende deelnemers aankoop. Hierdie bevinding is dus teenstrydig met Bonke (1996:295-296) en Manrique en Jensen $(1997 ; 1998)$ wat beweer dat die groter besteebare inkomste van dubbelberoep-huishoudings tot groter geriefsvoedselaankope lei.

Die ekonomiese klimaat Die deelnemers kom uit 'n middel- tot hoër sosio-ekonomiese groep wat gewoonlik ' $n$ relatief klein persentasie van hul besteebare inkomste aan voedsel spandeer. Die data vir hierdie studie is ingesamel in ' $n$ tyd toe voedselpryse vinnig gestyg het en verskeie aspekte soos ' $n$ daling in die wisselkoers word daarmee in verband gebring (Van Burick, 2002). Dit kon moontlik ook ' $n$ verklaring wees waarom sommige van die deelnemers $(c, g, h)$ minder geriefsvoedsel koop.

Interaksie van die huishouding met die fisiese omgewing Hierdie studie het plaasgevind in ' $n$ stedelike gebied waar ' $n$ groot verskeidenheid geriefsvoedsels geredelik in die winkels beskikbaar is. Beskikbaarheid beïnvloed ook voedselkeuse (Sims, 1981; Krondl, 1990:10). Hoewel hierdie studie nie op die winkels waar produkte gekoop word gefokus het nie, het die deelnemers spontaan daaroor gepraat. Dit wil dus lyk of die fisiese omgewing waar die produkte gekoop word die deelnemers se keuses mag beïnvloed. Een algemene gevoel was dat 'n spesifieke winkelgroep produkte van besondere hoë kwaliteit verkoop. Enkelinge koop graag daar vir spesiale geleenthede of omdat hulle glo dat die produkte langer vars en goed bly. Die hele atmosfeer ('ambience') van ' $n$ winkel dra by tot die persepsies of indrukke wat verbruikers het van die gehalte van die produkte wat daar gekoop word. Die deelnemers aanvaar oor die algemeen dat produkte van dié bepaalde winkelgroep van hoë gehalte is en dit kan ' $n$ uitvloeisel wees van die winkel se filosofie en bemarkingsboodskap (Haasbroek, 2002). Die res van die groep deelnemers se lojaliteit lê by winkels wat gerieflik geleë is en met wie se produkte en pryse hulle tevrede is. Volgens Rhee en Bell (2003) het verbruikers 'n primêre lojaliteit tot een betrokke winkel en doen hulle meeste van hul aankope daar.

Kriteria waaraan al die deelnemers kruidenierswinkels beoordeel het, is onder meer die volgende:

In die eerste plek word voedselprodukte verkieslik aangekoop by ' $n$ winkel wat gerieflik geleë is, veral een wat op hul daaglikse roete werk toe geleë is. Ligging en gerieflike parkering is dus van kardinale belang (Beharrel \& Denison, 1991; Levy \& Weitz, 2001:233).

Tweedens wil die individu as kliënt gewaardeer voel. "Mens koop graag by ' $n$ winkel waar jy die mense ken en jy voel dat jy belangrik is." (deelnemer $h$ )

"... die mense leer ' $n$ mens ken en hulle weet wat jy na soek." (deelnemer $\mathrm{d}$ )

Derdens wil die individu die versekering hê dat kwaliteit-produkte met sorg hanteer word.

“... waar aan die produk aandag gegee word - die kwaliteit daarvan. Jy vertrou dat die produkte vars is en met sorg hanteer is." (deelnemer $h$ )

"Jy los fisies jou kos in iemand anders se hande en dis " $n$ vertrouensverhouding vir my." (deelnemer $d$ )

Vierdens, ' $n$ groot omset, aangesien dit ' $n$ manier is om varsheid van bevrore produkte of volledig voorbereide geregte te beoordeel. 'n Deelnemer (a) stel dit as volg:

"Ek sal dit [voorbereide vis] nie by ' $\mathrm{n}$ ou kafeetjie of by 
so iets koop nie; jy koop dit by 'n winkel waar die omset groot is."

Vyfdens ' $n$ eenstopdiens waar alle voedselprodukte onder een dak gevind kan word. Hierdie tendens word ook gerapporteer deur Davies (1997).

"Ek koop gewoonlik alles daar, soos doeke ensovoorts ..." (deelnemer e)

"Ek hou daarvan om by een plek te koop. Ek koop nie hier en daar en daar nie ..." (deelnemer c)

Dit was veral die deelnemers met klein kindertjies $(e, f$ en g) wat laat blyk het dat kruideniersaankope stresvol kan wees as die kinders die uitstappie meemaak. Die kinders trek hulle aandag af en veroorsaak dat hulle nie alles gekoop kry wat hulle wou nie. Oor die algemeen beskou verbruikers kruiderniersaankope as stresvol vanweë die roetine-aard daarvan en daarom poog hulle om dit met die minimum insette af te handel (Beharrel \& Denison,1991; Aylott \& Mitchell,1999). Stressors, soos die kinders, kan selfs veroorsaak dat nuwe geriefsvoedselprodukte wat juis op beroepsvroue met kinders gemik word, nie raakgesien word nie.

"Dit is nogal werk om met kinders winkel toe te gaan. Ek koop nie graag saam met hulle groceries nie, hulle maak my mal. En hulle raak moeg. ... Jy kom nie terug met wat jy wou gehad het nie."

Verskillende strategieë word deur die deelnemers met klein kindertjies gevolg. Sommige (e en $\mathrm{f}$ ) verkies om gou na werk by ' $\mathrm{n}$ winkel langs te ry en die nodige te koop, terwyl ander (g) hul kinders tuis laat en met 'skuldoffers' tuiskom.

"P... is op my pad huis toe. Ek koop dan gewoonlik sommer alles daar soos doeke, ensovoorts".

"Ek het altyd hierdie skuldgevoel as ek lank in die winkels is en hulle moet by die huis bly - dan wil ek my gewete sus en dan bring ek vir hulle iets lekkers saam."

' $n$ Werkende ma wil eintlik nie haar kinders weer eens in die sorg van iemand anders laat as sy kruideniersware moet koop nie, maar doen dit tog omdat hulle haar aandag aftrek. Oplossings in dié verband kan uitdagings vir die toekoms wees, aangesien die plek van aankope so ' $n$ belangrike deel van die voedselskemata van die deelnemers uitmaak. Levy en Weitz (2001:7) sowel as Casabona (2002) stel voor dat die kleinhandelsomgewing ' $n$ unieke aankoopervaring behoort te bied, met die klem op vermaak (ook vir kinders) en verbruikersopvoeding. Sloan (1999) maak melding van spesiale kiosks waar maaltydoplossings aangebied word. Verder kan kruishandelswarevoorstelling (Casabona, 2002) in sulke kiosks die tyd wat aan voedselaankope spandeer word, verminder omdat alles bymekaar is.

Sosiokulturele faktore Voedselgebruike in die alledaagse lewe is deurspek met sosiale betekenis en assosiasies wat ook kultuurgebonde is. Kultuur word gedefinieer as "... the pattern of knowledge, concepts, values, attitudes, beliefs and traditions that are learned and transmitted between individuals, often from generation to generation" (Johns \& Kuhnlein,
1990:18). Kultuur kom ter sprake in verskeie fasette van die lewe, soos hoe voedsel gebruik word om te onthaal, in die intieme gesinskring, en so meer (Johns \& Kuhnlein, 1990:17; Falk et al, 1996; Asp, 1999). Voedsel kan as ' $n$ inherente deel van kultuur beskou word, aangesien voedselkeuses slegs gemaak word uit dit wat kultureel aanvaarbaar is (Rozin, 1996:101; Asp, 1999). Die vrou is ook dikwels die draer van kultuur in ' $n$ gemeenskap, veral waar dit by eetgewoontes kom. Die deelnemers is uit 'n homogene kultuurgroep (Blanke Afrikaanssprekendes) gekies en die subtiele invloed van kultuur, wat van jongs af deel van ' $n$ individu se lewe uitmaak, is waargeneem in die response van die deelnemers.

Die invloed van die ouerhuis kom ook in hierdie studie te sprake. Deelnemer (h) het in Zimbabwe grootgeword waar haar pa 'n slagter was en haar ma ' $n$ besondere groentetuin gehad het. Sy het haar liefde vir kwaliteit vleis en groente by haar ouers geleer en dit is steeds vir haar belangrik.

“... ek het grootgeword met ' $n$ waardering en 'n liefde vir mooi vleis, mooi gesnyde vleis. Ek weet wat is goeie vleis, en wat groente betref - my ma was so lief daarvoor."

Daarenteen het ' $n$ ander (d) se ma slegs bevrore groente en later net volledig voorbereide maaltye gebruik. Sy volg deesdae in haar ma se voetspore deurdat sy hoofsaaklik volledig voorbereide maaltye koop. "... my pa is oorlede toe ek in my derde jaar was. So het my ma ook begin, sy het nader aan S... getrek en sy het ook klaar voedsel gekoop en toe het ek gesien hoe oulik is dit."

Die invloed van die ouerhuis was ook duidelik waar ' $n$ deelnemer (a) aangedui het dat 'n gereg nie proe soos wat sy dit kan onthou uit haar kinderdae nie.

"Die gekoopte lasagne smaak nie soos tuisgemaakte, of dit waarmee ek groot geword het nie."

Die resultate van hierdie studie is dus in ooreenstemming met die bestaande literatuur oor die invloed van die ouerhuis (Johns \& Kuhnlein, 1990:17; Falk et al, 1996; Asp, 1999), die generasie asook die omgewing waarin die beroepsvrou grootgeword het (Sloan, 1998; 1999; Davies, 2001). Sommige voedsels / geregte wat in die ouerhuis voorberei is, is deesdae in geriefsvorm beskikbaar en dit bied die deelnemers die vryheid om keuses te maak wat by hul omstandighede en kultuur pas.

Kultuur is egter ook onderworpe aan verandering omdat individue onder andere blootgestel word aan die veranderende sosio-ekonomiese omstandighede, die kommunikasiemedia en so meer. 'n Bewys hiervan is waar die deelnemer ( $f$ ) haar besluit om geriefsvoedsel te gebruik, rasionaliseer:

"... hy [haar man] het aanvanklik vir my gesê - sy mahulle het hulle grootgemaak dat jy alles vars koop en self maak, want dis die goedkoopste en dit [geriefsvoedsel] was vir hom duur, tot ek op 'n stadium besluit het ek gaan nie meer verwerk nie. So ek gebruik omtrent nou - net vir kook gebruik ek hierdie gevriesde goeters. My ma het byvoorbeeld ook nie vreeslik ge- 
vriesde goed gebruik nie, so dit kom uit die agtergrond uit en ek dink mens word net wyser op 'n stadium en besef - dis nie regtig baie slegter om dit te gebruik nie."

Die deelnemers braai dikwels oor naweke vleis en doen dit selfs vir gaste. Suid-Afrika se klimaat leen hom uitsonderlik tot hierdie eg Suid-Afrikaanse tipe buitelugonthaal. Verder is gasvryheid ook inherent aan die kultuur. Feitlik al die deelnemers het aangedui dat hulle self kosmaak (behalwe d) wanneer hulle gaste vir ete kry, amper asof dit ondenkbaar is om geriefsvoedsel vir dié doel te koop.

"So nee, nooit geriefskos nie. Dis nogal snaaks dat jy dit noem, né."

"Naweke, van Vrydae, Saterdae en Sondae, maak ek kos en obviously as ons nou mense kry."

Sosiale en kulturele betekenisse van voedsel word op ' $n$ natuurlike en onbewustelike manier oorgedra as gevolg van die samestelling en dinamika van die sosiale omgewing waarin individue hulle bevind. Om hierdie rede verskaf gesinne en huishoudings van die belangrikste interpersoonlike verhoudings wat voedselkeuses beïnvloed en kultureel aanvaarbare gebruike oordra. Die sosio-kulturele faktore beïnvloed ook tot ' $n$ groot mate die tipe voedsel wat deur die deelnemers gekies word vir maaltye gedurende die week, die naweek en wanneer gaste vir ete genooi word. As gevolg van die verweefdheid van sosio-kulturele faktore, sou dit as ' $n$ eenheid bestudeer kon word vir kultureel homogene groepe.

\section{SAMEVATTING}

Voedselkeuse is ' $n$ dinamiese, komplekse proses wat deur talle faktore beïnvloed word wat op hul beurt ook onderling met mekaar verband hou. Die konteks en omstandighede waarbinne die beroepsvrou haar bevind, kan haar voedselkeuses rig. Eerstens is die nabye omgewing van belang omdat verbruikersgedrag beter verstaan kan word teen die agtergrond van die spesifieke geleentheid of situasie. Dit bepaal wat geskik is vir gesinsmaaltye en vir gaste (Verlegh \& Candel, 1999). Gedurende die week kan tydsdruk byvoorbeeld ' $n$ belangrike oorweging wees vir die keuse van geriefsvoedsel, terwyl daar oor naweke meer tyd beskikbaar is om maaltye van meet af te berei. Enkellopendes blyk geneigd te wees om geriefsvoedsel te koop aangesien dit nie lekker is om alleen voedsel voor te berei of te eet nie. Hulle het ook net hul eie behoeftes om te bevredig teenoor gesinne waar ' $n$ man en kinders se behoeftes en voorkeure in ag geneem moet word. Dit lyk dus of sosiale faktore ' $n$ baie belangrike rol in die voedselkeuse van beroepsvroue speel.

Die wyere sosiale omgewing beïnvloed skynbaar ook die geriefsvoedselkeuses wat gemaak word. Dit verskaf die konteks waarbinne beroepsvroue hulle keuses uitoefen aangesien dit verband hou met hul werk, geld, die mense met wie hul in interaksie is en selfs die winkels waar hulle koop. Ekonomiese faktore bepaal onder andere die besteebare inkomste, die tipe woning en die addisionele hulp wat die beroepsvrou tot haar beskikking het, en dit het weer ' $n$ invloed op haar tyd en die tipe voedsel wat gekoop word. Die fisiese omgewing, oftewel die winkel, speel 'n bepaalde rol in die algemene indrukke wat die deelnemers van produkte het. Verder moet aspekte soos ' $n$ gerieflike ligging, 'n eenstopdiens en vriendelike personeel nie onderskat word as aspekte wat voedselkeuse kan beïnvloed nie. Die subtiele invloed van kultuur moet ook nie uit die oog verloor word nie. Die invloed van die ouerhuis en bepaalde tradisionele gebruike, soos om te braai, speel ' $n$ definitiewe rol in die voedselkeuse van hierdie deelnemers.

Tenslotte word die volgende sterk beklemtoon: Die mate waartoe die bevindinge van hierdie studie toegepas kan word op ' $n$ ander konteks en respondente, berus by die leser van hierdie artikel. Babbie en Mouton (2001:277) stel dit so: “... in a qualitative study the obligation for demonstrating transferability rests on those who wish to apply it to the receiving context (the reader of the study)." Hoewel die bevindinge van hierdie navorsing hopelik wyere begrip van die onderwerp gee, bied dit slegs ' $n$ teoretiese raamwerk waarbinne soortgelyke navoring aangepak kan word.

\section{LITERATUURVERWYSINGSLYS}

ASP, EH. 1999. Factors affecting food decisions made by individual consumers. Food Policy 24:287294.

ASSAEL, H. 1992. Consumer behavior and marketing action. $4^{\text {th }}$ Ed. Boston. PWS-Kent.

AYLOTT, R \& MITCHELL, V. 1999. An exploratory study of grocery shopping stressors. British Food Journal 101(9):683-700.

BABBIE, E \& MOUTON, J. 2001. The practice of social research. South African Ed. Cape Town. Oxford University Press.

BEHARREL, B \& DENISON, T. 1991. Food choice in a retail environment. British Food Journal 93(7):2430.

BLADES, M. 2001. Factors affecting what we eat. Nutrition and Food Science 31(2):71-74.

BLAYLOCK, J, SMALLWOOD, D, KASSEL, K, VARIYAM, J \& ALDRICH, L. 1999. Economics, food choices and nutrition. Food Policy 24(2-3):269-286.

BONKE, J. 1996. Economic influences on food choice. In MEISELMAN, HL \& MACFIE, HJH. 1996. Food choice, acceptance and consumption. London. Blackie Academic \& Professional.

BOTHA, P. 2001. Die kwalitatiewe onderhoud as data-insamelingstegniek; sterk en swak punte. Tydskrif vir Gesinsekologie en Verbruikerswetenskappe 29:13-19.

BRECH, DM. 1998. The food service industry as a support for employed mothers. Journal of Family and Consumer Sciences (Summer):20-22.

BUBOLZ, MH \& SONTAG, MS. 1993. Human ecology theory. In BOSS, GH, DOHERTY, GH, LAROSSA, R, SCHUMM, WR \& STEINMETZ, SK. (Eds). Sourcebook of family theories and methods. A contextual approach. New York. Plenum. 
CANDEL, MJJM. 2001. Consumers' convenience orientation towards meal preparation: conceptualization and measurement. Appetite 36:1528.

CASABONA, L. 2002. Cow-tow; retailers moo-ve to milk the dairy aisle for all it's worth, using promotion and the arrival of brand names to generate greater sales. Supermarket News (August):17-20.

CATTERALL, M \& IBBOTSON, P. 2000. Using projective techniques in eduction research. British Educational Research Journal 26(2):245-257.

DAVIES, DL. 2001. Review of the UK marketplace for convenience foods. Nutrition and Food Science 31 (6):319-335.

DAVIES, G. 1997. Time, food shopping and food preparation: some attitudinal linkages. British Food Journal 99(3):80-88.

DEACON, RE \& FIREBAUGH, FM. 1988. Family resource management: principles and applications. Needham Heights, MA. Allyn and Bacon.

DECROP, A. 1999. Triangulation in qualitative tourism research. Tourism Management 20:157-161.

DE VOS, AS. 2002. Combined quantitative and qualitative approach. In DE VOS, AS, STRYDOM, $\mathrm{H}$, FOUCHé, CB \& DELPORT, CSL. Research at grass roots. $2^{\text {nd }} \mathrm{Ed}$. Pretoria. Van Schaik.

ESHLEMAN, JR. 1994. The family. $7^{\text {th }}$ Ed. Boston. Allyn \& Bacon.

FALK, LW, BISOGNI, CA \& SOBAL, J. 1996. Food choice processes in older adults: a qualitative investigation. Journal of Nutrition Education 28:257265.

FIELDHOUSE, P. 1995. Food and nutrition. Customs and culture. $2^{\text {nd }}$ Ed. London. Chapman \& Hall.

FURST, T, CONNORS, M, BISOGNI, CA, SOBAL, J \& FALK, LW. 1996. Food choice: a conceptual model of the process. Appetite 26:247-266.

GOFTON, L. 1995. Dollar rich and time poor? British Food Journal 97(10):11-16.

GREEFF, M. 2002. Information collection: interviewing. In DE VOS, AS, STRYDOM, $\mathrm{H}$, FOUCHé, CB \& DELPORT, CSL. 2002. Research at grass roots. $2^{\text {nd }} \mathrm{Ed}$. Pretoria. Van Schaik.

HAASBROEK, W. 2002. Woolies food philosophies. Food Review (March):10-11.

HAMMERSLEY, M \& ATKINSON, P. 1995. Ethnography. $2^{\text {nd }}$ Ed. London. Routledge.

HOLLANDER, SL. 1988. Projective techniques uncover real consumer attitudes. Marketing News 22 (1):34.

JAE, MK, RYE, JS \& ABDEL-GHANY, M. 2000. Family characteristics and convenience food expenditure in urban Korea. Journal of Consumer Studies and Home Economics 24(December):252256.

JOHNS, T \& KUHNLEIN, HV. 1990. Cultural determinants of food selection and behaviour. In ANDERSON, GH. 1990. Diet and behaviour: multidisciplinary approaches. London. SpringerVerlag.

KOK, M. 2003. Bepaalde beroepsvroue se persepsies van geriefsvoedsels in die keuse, aankoop en gebruik daarvan. Ongepubliseerde Magistertesis in Verbruikerswetenskap (Voedselbestuur).
Universiteit van Pretoria

KRONDL, M. 1990. Conceptual models. In ANDERSON, HG. 1990. Diet and behaviour. Multidisciplinary approaches. London. SpringerVerlag.

KRONDL, M \& COLEMAN, MS. 1988. The role of food perceptions in food use. Current Concepts in Nutrition 16:53-78.

KUPIEC, B \& REVELL, B. 2001. Measuring consumer quality judgements. British Food Journal 103(1):7-22.

LAUTMAN, MR. 1982. Focus groups: theory and method. Advances in Consumer Research XIX:52-55. LAWLESS, HT \& HEYMAN, H. 1998. Sensory evaluation of food. Principles and practices. New York. Chapman \& Hall.

LEEDY, PD.\& ORMROD, JE. 2001. Practical research. Planning and design. $7^{\text {th }}$ Ed. New Jersey. Prentice-Hall.

LEVY, M \& WEITZ, BA. 2001. Retailing management. Boston. Mc Graw-Hill Irwin.

MADILL-MARSHALL, JJ, HESLOP, L \& DUXBURY, L.1995. Coping with household stress in the 1990s: Who uses "convenience foods" and do they help? Advances in Consumer Research 22:729-735

MANRIQUE, J \& JENSEN, HH. 1997. Spanish household demand for convenience meat products. Agribusiness 13(6):579-586.

MANRIQUE, J \& JENSEN, HH. 1998. Working women and expenditures on food away-from-home and at-home in Spain. Journal of Agricultural Economics 49(3):321-333.

NEUMAN, WL. 2000. Social research methods. Qualitative and quantitative approaches. $4^{\text {th }} \mathrm{Ed}$. Boston. Allyn \& Bacon.

OAKLEY, A. 1981. Interviewing women: a contradiction in terms. In ROBERTS, $\mathrm{H}$. Doing feminist researches. London. Routledge \& Kegan Paul.

OLSON, JC. 1981. The importance of cognitive processes and existing knowledge structures for understanding food acceptance. In SOLMS, J \& HALL, RJ. 1981. Criteria of Food Acceptance. Zurich. Forster Verlag AG.

RHEE, H \& BELL, DR. 2003. The inter-store mobility of supermarket shoppers. Journal of Retailing 78 (4):225-237.

ROSE, GM, KAHLE, LR \& SHOHAM, AS. 1995. The influence of employment status and personal values on time related food consumption behavior and opinion leadership. Advances in Consumer Research 22:367-373.

ROZIN, P. 1996. The socio-cultural context of eating and food choice. In MEISELMAN, HL \& MACFIE, $\mathrm{HJH}$. 1996. Food choice, acceptance and consumption. London. Blackie Academic \& Professional.

SHEPHERD, R \& SPARKS, P. 1994. Modeling food choice. In MACFIE, HJH \& THOMSON, DMH. 1994. Measurement of Food Preferences. London. Blackie Academic \& Professional.

SIMS, LS. 1981. Further thoughts on research perspectives in nutrition education. Journal of Nutrition Education 13(1):S70-S75.

SLOAN, AE. 1998. Food industry forecast: 
Consumer trends to 2020 and beyond. Food Technology 52(1):37-44.

SLOAN, AE. 1999. Top ten trends to watch and work on for the millennium. Food Technology 53(8):40-60. SOLOMON, MR. 1994. Consumer behaviour. Buying, having and being. Boston. Allyn \& Bacon. STRYDOM, H \& VENTER, L. 2002. Sampling and sampling methods. In DE VOS, AS, STRYDOM, H, FOUCHé, CB \& DELPORT, CSL. Research at grass roots. $2^{\text {nd }} E d$. Pretoria. Van Schaik.

TAYLOR, SJ \& BOGDAN, JR. 1984. Introduction to qualitative research methods. The search for meanings. $2^{\text {nd }}$ Ed. New York. John Wiley.
TILLOTSON, JE. 2001. Our ready-prepared readyto-eat nation. Nutrition Today 37(1):36-38.

VAN BURICK, N. 2002. Gemengde reaksie op redes vir hoër kospryse. Landbouweekblad 27 (September):79.

VERLEGH, PWJ \& CANDEL, MJJM. 1999. The consumption of convenience foods: reference groups and eating situations. Food Quality and Preference 10:457-464.

WILL, V, EADIE, D \& MACASKILL, S. 1996.

Projective and enabling techniques explored. Qualitative Market Research 14(6):38-43. 